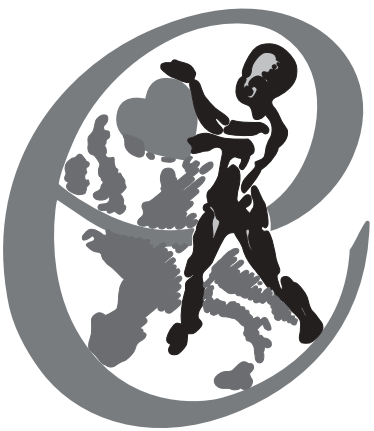

\title{
The Association for European Paediatric Cardiology L'Association Européenne pour la Cardiologie Pédiatrique
}

\section{Newsletter}

$\mathrm{T}$ HE YEAR 2008 BRINGS WITH IT NEW CHALLENGES. We hope that all our members will enjoy the year successfully, both professionally and in personal life.

The Association has already received plentiful new members. The advantages of membership are subscription to Cardiology in the Young, reduced registration fees for the Annual meeting, but perhaps most importantly, the support provided by the communal activities of the Association. We urge, therefore, all our existing members to encourage their colleagues who are not yet members to join the Association. Our aim is that all specialists working in the field of paediatric cardiology and its related disciplines should also be members of our Association. In particular, we encourage all those currently in training to join as junior members. One of our major aims is to promote teaching and training in all aspects of Cardiology in the Young. We now organize several courses that support the needs of our juniors in clinical training and decision making. At the same time, the Association itself needs the new and refreshing ideas that can be brought to our activities by our junior members. Thus, the Council urges all those involved in training to persuade their trainees to join the Association. The procedures for application have now been simplified, and on-line application is available. Please consult the website of the Association at www.aepc.org for more information.

\section{Annual Subscription}

All members will have received a letter from the Treasurer in January. It contains information about how to pay the annual subscription. The membership fee will cover the contribution to the Society, entitle all properly accredited members to receive Cardiology in the Young, and include membership of one Working Group, of their choice. Members should select their chosen Working Group, and send this information to the Secretary-General and the Treasurer. Members may also belong to more than one Working Group, albeit that a small fee will be payable when joining additional groups. Many of us work in integrated teams, and cover work represented by several Working Groups.

It is now easy to pay the annual subscription on-line, but first members need to register. When registering, it will be possible to create individual usernames and passwords. Registering is also important so that the Treasurer is able to identify payment of the annual subscription. Those already registered should have received their usernames and passwords from the Secretary-General in 2006, or when they were accepted as members of the Association. Those who may have forgotten their passwords or usernames should not hesitate to contact the Secretary-General. It is also easy to check, and if needed, change addresses online, and also to check the information that is stored in the data base. It is only possible, however, for members to examine their own information. Please remember always to change this information via the webpage www.aepc.org should there be changes in the mailing address, e-mail address, or any other information. Only when we hold accurate contact information, and know that the annual subscription has been paid, can we ensure that all our members receive their full benefits. This includes, of course, a regular paper copy of Cardiology in the Young, as well as online access to all numbers of the Journal.

\section{Replacement of Councillor}

It will be necessary for Council to replace one Councillor during the 43rd Annual Meeting, to be held in Venice. It is proposed by Council that the term of the Treasurer, Klaus Schmidt, be extended by one year, until 2009. Luc Mertens will be replaced in Venice, and it is the hope of Council that the new Councillor will assume the duties of Treasurer in 2009. 
Our current members of Council are:

- André Bozio, Lyon, President

- András Szatmári, Budapest, past-President. The term of András ends in 2008, during the Annual Meeting in Venice.

- Eero Jokinen, Helsinki, Secretary-General

- Joseph deGiovanni, Birmingham, Scientific Secretary

- Klaus Schmidt, Dusseldorf, Treasurer

- Bohdan Maruszewski, Warsaw, Councillor, representing also our Cardiac Surgeons

- Gerald Tulzer, Linz, Councillor

- Luc Mertens, Leuven, Councillor, to be replaced in Venice

- Ornella Milanesi, Padova, local organizer of the 43rd Meeting. Her term will end in 2008 during Annual Meeting in Venice

- Tara Bharucha, Southampton, Junior Councillor.

The contribution of the membership in replacing the Councillor is vital. The more nominations received by Council from the members, the more open and democratic will our Association become. Forms to be used in nominations have been issued by mail in January. We encourage all our members to take advantage of the privilege to propose members of Council.

Nominations for Councillor must be signed by at least five ordinary members from two or more countries, and should be received by the SecretaryGeneral at least four months before the next Annual Meeting. As a rule, at any one time there should be only one Councillor or Officer from the same country within the Council.

\section{Annual Meeting, 2008}

Our 43rd Annual Meeting will be held in Venice Lido, Italy, from May 21 through 24. The meeting will be a joint one between the Association and the European Congenital Heart Surgeons' Association. The Scientific Secretary, Joseph deGiovanni, and the Local Chairmen, Ornella Milanesi and Giovanni Stellin, together with local scientific committee, have worked hard to produce a rewarding scientific and social programme. The Council is sure that the programme will provide paediatric cardiologists, congenital cardiac surgeons, and all other professionals associated with these disciplines, with much new and interesting information.

As a council, we are pleased to announce that this year we have received more than 500 abstracts, which are currently being screened by a panel of reviewers. On the basis of the scores received, we will select oral and poster presentations. As usual, there will be three prizes for the best posters, and

also as in previous years, junior participants will receive particular consideration. The prizes will be distributed during the Social Evening of the meeting. We are looking forward to seeing great numbers in Venice, and we encourage all our members not only to come themselves, but also to bring their colleagues and juniors. The 43rd Annual meeting will provide the opportunity for personal exchange of ideas, thoughts, and knowledge, as well as spending enjoyable hours together with friends.

The meeting this year also gives participants a splendid opportunity to explore Venice, and to become acquainted with a significant part of the fascinating history of Europe. The nearby University of Padua, dating from 1222, is the second oldest University in Italy, and the second oldest Medical School in the world. Founding fathers of modern cardiology such as Andrea Vesalio, Realdo Colombo, Gabriele Falloppio, and Fabrizio d'Acquapendente all studied and taught in its prestigious anatomical theatre. William Harvey, who first described the circulation of blood, as documented in the famous book "De Motu Cordis", graduated in Padua in 1602.

\section{The 'Update on' Course during the 43rd Annual Meeting}

From 2008 on, we will rename our teaching course as the "Update-on" Course. This year, the course will be organized by the Working Group on Paediatric Cardiovascular Intensive Care. It will take place on Wednesday, 21 May. The programme is most interesting, and will instruct and update not only junior members, but also all other paediatric cardiologists and surgeons.

\section{Special Training Courses}

Our Basic Course on Paediatric Cardiac Morphology will have been held in Padua, Italy in May, 2008. The Basic Teaching Course in Echocardiography will take place in Barcelona, Spain, in October, 2008. For more information, please visit the Association's web page at http://www.aepc.org. These courses are designed to be of small size, and affordable, not only in terms of fees, but also for accommodation and travel expenses. Please encourage your Junior Fellows to register soon. The number of attendees accepted is limited.

In closing our opening Newsletter of 2008, we look forward, on behalf of all our members of Council, to welcoming you at the Annual Meeting in Venice in great numbers!

André Bozio

President
Eero Jokinen

Secretary-General 